1991-92 APSA African-American Graduate Fellows

\section{Funded Fellows}

Nancy Kwang Johnson, Cornell University

Jovan Jones, University of North Carolina, Chapel Hill

Pamela Sutton, Washington University

\section{Non-funded Fellows}

Janeen L. Birckhead, Hampton University

Jonathan Brasfield, University of Arkansas, Monticello

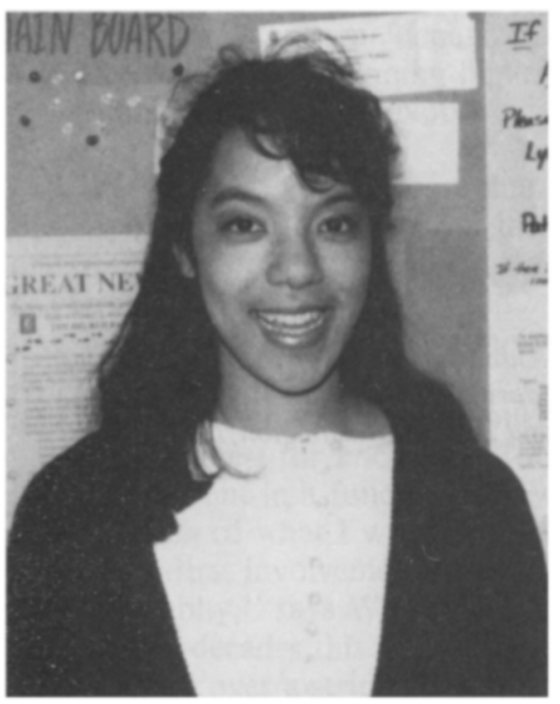

Nancy Kwang Johnson

Teresa J. Burl, University of Arkansas, Little Rock

Dean A. Calloway, University of Washington

Laurette Coles, New York Institute of Technology

Maurella Cunningham, Carleton College

Tina L. Evans, Texas Woman's University

Stephen E. Hart, Oakland University

Kimberly Henderson, Georgetown University

Michelle Iseminger, Franklin \& Marshall College

Joyce Johnson, University of the
District of Columbia

Olivia Jones, Florida A\&M University

Jason Kirksey, Oklahoma State University

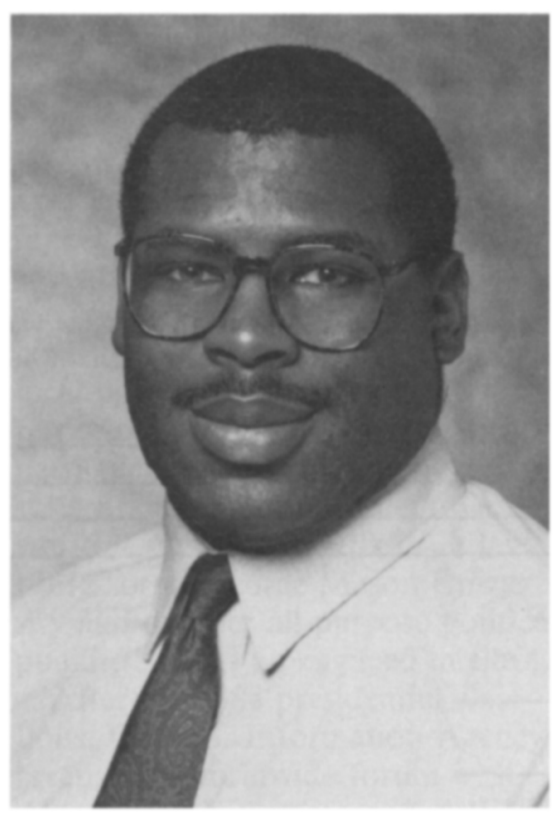

Jason Kirksey

Cherise G. Moore, University of California, Los Angeles

Sherrie D. Russell, Xavier University, New Orleans

James W. Smith, Hampton University

James Smylie, Sangamon State University

Mark Walker, Massachusetts Institute of Technology

La Trice M. Washington, St. Augustine's College

Crystal E. Wright, University of New Mexico

The names, addresses and background information for both the Latino and African-American Fellows were sent to every graduate political science program in the U.S. so that all named Fellows would be considered for graduate school and for funding.
Editor's Note: The following article on Ronald Waters first appeared in The Washington Post (Nov. 8, 1990). Walters is presently a member of the APSA Council.

\section{Washington's Political Answer Man: Howard's Ronald Walters, the Activist-Observer}

\section{Jacqueline Trescott \\ Washington Post Staff Writer}

Immediately after his appearances on two television news programs election night, Ronald Walters went to Sharon Pratt Dixon's victory party. He had talked about the mandate. Now he wanted to see it.

"I wanted to see en masse who the Dixon people were. You get a flavor when you are right there," says Walters, the chairman of Howard University's political science department and an activist and scholar who has been one of the most visible commentators on this year's complex political season in Washington.

It is not unusual for Walters to do some unorthodox research away from the Ebony Tower, right at the scene of political science in the making. On the morning the U.S. Senate voted to uphold President Bush's veto of the 1990 Civil Rights Act, Walters was in the gallery. When L. Douglas Wilder was elected governor of Virginia, Walters got on a bus and went to Richmond to be there when Wilder claimed victory. Years ago, Walters helped organize a group of Washingtonians to oppose the content of a play on Paul Robeson, and picketed the theater.

His method, he says as he tries to neatly delineate his interests, can only be described with the academic argot. "In a way it is the synthesis between social science and the involvement of personal experiences."

Yet, there's no time for reflection on television in the frenzy of election night.

Renee Poussaint of Channel 7 threw the central question of the mayoral election to Walters.

Was Dixon's whopping margin a mandate? "Politically, yes it is a mandate," Walters began. He managed a few more words. The studio lights bounced off his black-rimmed 


\title{
1991 ANNUAL MEETING CHILD CARE SERVICE
}

The American Political Science Association will sponsor a Child Care Service at the 1991 Annual Meeting in Washington, D.C., August 29 - September 1, 1991. This service is offered at no charge for unlimited use to children of registrants at the 1991 Annual Meeting. In order to reserve a place, a $\$ 25$ non-refundable deposit per child is required with pre-registration.

Beginning on Thursday, August 29, the service will be available daily in the Washington Hilton. The hours are 8:00 a.m. to 10:00 p.m., except on Sunday, September 1 when the hours are adjusted to 8:30 a.m. to 12:30 p.m. Snacks will be available for the children.

Parents will be asked to complete a tentative schedule following their pre-registration for child care service. Children must be picked up promptly at the appointed time. Diapers, special milk or formula, as well as any written special feeding isntructions should be supplied by the parents. Lunch and/or dinner must be provided by the parents.

If your child has a favorite toy or game, it should be labeled with the child's name and the caretakers will do their best to see that it is returned. However, responsibility for the loss of any personal property cannot be assumed.

\section{Parents' Name: \\ Home Address:}

Home Phone:

Child/Children Name(s), Age(s), Weight:

1.

2.

3.

We, the parents of (the children listed above), hereby give our consent to any licensed physician at, with, or from any accredited hospital to administer any medical care or medication to the above named child/children during our absence from them while attending the American Political Science Association Annual Meeting at the Washington Hilton and Towers, Washington, D. C. , August 29 - September 1, 1991.

Mother's signature:

Father's signature:

\section{ALL CHILDREN WHO USE THE SERVICE MUST BE PRE-REGISTERED WITH DEPOSIT FOR EACH CHILD RECEIVED BY JULY 15, 1991. THERE WILL BE LIMITED ON-SITE REGISTRATION AT A \$40 FEE.}

List name, address, and telephone number of any legal next of kin we may contact if you are unreachable. If this contact is necessary, a collect telephone call will be placed to the next of kin listed below for notification.

Name, City, State, Area Code and Telephone Number

\author{
Return completed forms to: \\ Child Care Coordinator \\ American Political Science Association \\ 1527 New Hampshire Avenue NW \\ Washington, D.C. 20036
}

Please return this form no later than July 15, 1991. 
glasses. He looked unmistakably lettered and staid in a gray jacket, gray tie and blue vest.

Then Susan King asked the second fundamental question of the night. What happened to Marion Barry? "What people are saying-it is time to move on," said Walters, fighting to edit years of expounding into an electronic teaspoon of wisdom.

\section{A Need to Know}

On the wall in Walters's airy L-shaped office in Frederick Douglass Hall on Howard's campus is a formal portrait of Ralph Bunche. An intellectual eminence at Howard from 1928 to 1941 , Bunche was once the chairman of the same department and afterward had a stunning diplomatic career and won the Nobel peace prize in 1950 .

Walters glances at this larger-thanlife inspiration as he talks about his own multifaceted life in politics. He has written nearly 100 articles and four books since 1986. "It is almost an insatiable desire to know ... . almost in an old-fashioned way but not just the quest for knowledge for its own sake but in a functional way ... so much of what I write about because of that involvement is running biography," says Walters.

For three decades this slight man, polka-dot tie over a striped suit, only his tinsel-thin strands of wavy gray hair hinting at his 53 years, has been in the fray-shaping strategy for black politicians. He has known the players for decades and has emerged as one himself. Jesse Jackson calls him "necessary," saying he telephones Walters at all sorts of "wicked hours."

As his reputation expanded, Walters began to be consulted on issues beyond black politics.

At Howard that bobbing from the active to the academic has been lauded while those who think Walters does too much are quiet about it.

"The normal run of political scientists are not involved in this fast pace of elections," Walters admits with a laugh.

His diversity has worked well for him, says Linda Williams, a research fellow at the Kennedy School of Government at Harvard University. "He knows all the political operatives and all the protest workers." Elaine Kamarck, a senior fellow at the Progressive Policy Institute, worked for the campaigns of Jimmy Carter, Walter Mondale and Bruce Babbitt. Though she and Walters have had opposing views, she says, "When people disagree with his politics, they agreed he is solid. He makes a good case for himself."

At times Walters might seem to be the peripatetic protester, facilitator, observer and commentator. Beyond local politics, he carries an equally respected portfolio in foreign policy, particularly African politics. "Ron cares about what happens in the world," says Roger Wilkins, a law professor at George Mason University and another all-purpose political pundit. "His is an engaged intellect."

After the 1988 presidential elections, the U.S. Information Agency arranged a worldwide forum with American commentators, and Walters and his students participated from his office.

Two years ago 1,000 black executives and politicians met in New Orleans for a three-day African American Summit. Walters's job was to pull together the final statement. "He was in the back, alone, papers under his feet, on his lap and on both sides of his desk. He was doing the collating and," says Samuel Yette, a journalist and photographer, "people depend on him to do that."

What bothers some who have watched the broadening of Walters's audience is they feel he is still pigeonholed. Walters himself is perplexed at his delayed discovery and questions whether white pundits get greater rewards.

"One of the unfortunate legacies of racial stereotyping is it is assumed that black intellectuals are only intellectuals on black America," says television journalist Kojo Nnamdi. Joyce Ladner, a sociologist and vice president at Howard, agrees. "The next stage should be that having seen he has a lot of smarts about things that have nothing to do with race, he will be brought out more."

Right now Walters is having his own debate, one similar to the entertainers who are proclaimed overnight successes, pursue the limelight and then cry for privacy, afraid of overexposure. After "running all over town," he says he's pulling back. "I am interested in the quality of what people want me to do," he says. Too many comments, he says, "makes people think you are a dilettante but with me I do have a legitimate focus in both of these areas. . . . You have to be careful."'

At the same time, he says, "Elections are a big public festival and everyone handicaps the elections. It's the biggest game in town."

\section{Revisionist History}

Walters is perhaps the griot of black politics.

He's been everywhere, hosting the planning sessions for the watershed Gary, Ind., black political convention in 1972, meeting with three other people in a Washington living room when the idea for the TransAfrica lobby was shaped, and taking notes at the historic meeting on which a black presidential bid was endorsed by black leaders.

But Walters can step back further in the chronology of modern black activism. He grew up in Wichita, Kans., the first of seven children of a military man/jazz musician and a homemaker. On an August day in 1958 he led what he calls the first modern sit-in at a drugstore in Wichita. He says this with passion, asking you to erase the image of those students sitting at a Greensboro, N.C., five-and-ten. When he was a consultant to "Eyes on the Prize" he gave his revisionist speech and recently has come up with clippings to prove it.

"Everytime I hear somebody talk about Greensboro, I go off," he says. Then the president of the local NAACP youth group, he was sent to a national WYCA/YMCA conference to present a civil rights plank. He was successful, except his speech on the floor was interrupted by the arrival of Eleanor Roosevelt, a story he tells with a laugh. At the same conference, he met his wife of 27 years, Patricia. For the last 15 years, she has been a social worker in 
Montgomery County. Her job, he says, "keeps me rooted in reality."

Almost 25 years ago, when the civil rights and black power movements prompted college students to demand black studies curricula, Walters was teaching at Syracuse University, where he helped start a course in black politics. After that Walters, who graduated from Fisk University and earned his advanced degrees from American University, established the Afro-American studies department at Brandeis University, becoming its first chairman.

"We thought we could make a tremendous contribution to the liberation of black people," says Walters.

What has filtered down from those efforts are a number of now-established university programs and the current debate over the Afrocentric curriculum. "If you posture black studies as something to correct someone's self-esteem, I don't think that is the central mission," Walters says. "I think what we are talking about is teaching the truth, teaching the facts. I want to separate that from going into a classroom and cheerleading."

By 1972 black politics no longer had one dominant personality-there were enough blacks on Capitol Hill to form a caucus-or only one issue. Walters helped Walter Fauntroy, Richard Hatcher, and Amiri Baraka plan the Gary convention and 10,000 people showed up. "The strategy developed, which was taken by Amiri Bataka to both parties, was a way of saying we are serious about this model of politics," says Walters. The implementation came years later. "It turned out the best vehicle was a presidential campaign."

\section{The Seriousness Test}

After a series of disappointments with the Democratic and Republican parties-basically because Walters viewed the party chiefs and candidates as patronizing-the members of the Black Leadership Forum met in 1983 to discuss a presidential campaign.

"The question came up, who is going to do it." Up to this point Jackson hadn't passed Walters's seriousness test. Over a period of time
Walters says he saw a serious, industrious, honest and brilliant man. "It takes a special mind," says Walters, to take four or five points minutes before a speech and then deliver it "in some of the most creative ways, not just giving it back but giving it back in metaphor and biblical ways." And Jackson credits Walters, his deputy campaign manager in 1984 and a consultant in 1988, with providing historical framework and details; the man who personified Jackson's memorable "text without context is pretext."

Jackson did not get a yes man. William Galston, issues director for Mondale in 1984 and a political scientist at the University of Maryland, remembers some tough bargaining sessions at that year's convention. "This was not someone who was just following Jackson's orders. He was a forceful but fair advocate. And he is very good at separating out the political dimensions of disagreement from the personal dimensions of conflict."

And Walters had fun. Even when he was wondering if this was the way history was made, marching in a small town in Texas with "flags flying and we don't have a vote within miles of here and Jesse saying we are doing it because it is right."

Because Walters has known Marion Barry since 1960 when they met at Fisk, he brought a long and personal view to his take on the Barry defeat. "I was surprised he was 10 percent off his base. I guess there was a tradeoff, people were sympathetic and mad as hell about the sentencing. But they didn't want someone on the council with those problems hanging over their head."

And with five women among the top vote-getters in the city, Walters says an old notion about the District voters has finally been broken. "That ought to put to rest the view that women wouldn't vote for another woman. It started with Patricia Harris and the view that the ministers wouldn't turn out for her and that the women voters would follow," says Walters. What about the size of the women's mandate, 88 percent for Dixon; 76 percent for D.C. Del.-elect Eleanor Holmes Norton? "Well, the size of Dixon's victory was a surprise," says Walters, still mulling over the mandate.

\section{Principles for College \\ Publishing Stated by Association of American Publishers, Inc.}

The Higher Education Division of the Association of American Publishers (AAP) has set the following guidelines for textbook publishing firms regarding criteria for textbook selection. The Committee on Professional Ethics, Rights and Freedoms of APSA has reviewed these guidelines, and believes that political science faculty should follow the spirit of the guidelines as set forth for publishers, with the added observation that the Committee regards the cost of a textbook, along with its quality, as a relevant consideration in its selection.

The guidelines published by AAP are as follows:

The Higher Education Division believes that the criteria for textbook selection properly concern only the quality of the textbook itself and its immediate ancillary materials.

The Higher Education Division recommends that college publishers follow the guidelines set forth below to ensure that their individual competitive practices do not lead away from this focus on educational materals because of payments of money or other consideration, directly or indirectly, to the benefit of individuals or academic departments (other than normally accepted entertainment practices and common courtesies).

Individual publishers' policies for textbook adoption should be universally applied and openly stated.

College publishers should avoid making any improper inducement to any actual or potential adopter, directly or indirectly, which may be described as a bribe, kickback or excessive commission or fee which is contingent on the adoption of their textbooks or their ancillary materials.

Unacceptable activities include, but are not limited to, the following:

- Providing cash grants, allowances or "rebates" to individuals other than students, book- 